\title{
INOVASI PEMANFAATAN EKSTRAK ALGA HIJAU Ulva $s p$ dari PANTAI LUK,SUMBAWA SEBAGAI KANDIDAT ANTIBAKTERI TERHADAP Salmonella thypi dan Staphylococcus aureus
}

\author{
Rian Adha Ardinata ${ }^{*}$, Yulianti $^{2}$, Asmawati $^{2}$, Yunianti $^{2}$, Baso Manguntungi $^{2}$ \\ ${ }^{1 *}$ Program Studi Manajemen Inovasi, Program Magister Universitas Teknologi Sumbawa \\ ${ }^{2}$ Fakultas Teknobiologi Universitas Teknologi Sumbawa \\ *Corresponding Author email: ${ }^{1}$ adha.rian1995@gmail.com, ${ }^{2}$ baso.Manguntungi@uts.ac,id
}

\begin{tabular}{|c|c|}
\hline & Abstrak \\
\hline $\begin{array}{l}\text { Diterima : } \\
\text { Bulan September } \\
2020\end{array}$ & $\begin{array}{l}\text { Indonesia termasuk negara maritim yang memiliki sumber kekayaan alam laut yang } \\
\text { melimpah. Salah satunya yaitu alga yang persebarannya hampir di seluruh perairan } \\
\text { Indonesia termasuk di kawasan laut Luk, Sumbawa. Salah jenis alga potensial yang } \\
\text { memiliki paling banyak kandungan senyawa metabolit primer dan sekunder adalah alga } \\
\text { hijau. Penelitian ini dilakukan bertujuan untuk mengetahui aktivitas antibakteri ekstrak }\end{array}$ \\
\hline $\begin{array}{l}\text { Diterbitkan: } \\
\text { Bulan Oktober } \\
2020\end{array}$ & $\begin{array}{l}\text { kasar alga hijau dari pantai Luk. Penelitian ini meliputi pengidentifikasian alga hijau } \\
\text { berdasarkan ciri morfologi, dilanjutkan dengan mengekstraksi alga hijau menggunakan } \\
\text { metode maserasi dengan pelarut akuades yang sebelumnya dilakukan tiga preparasi } \\
\text { sampel yaitu pengeringan }\left(27{ }^{\circ} \mathrm{C}\right) \text {, pemanasan }\left(70-80{ }^{\circ} \mathrm{C}\right) \text { dan pendinginan }\left(-10{ }^{\circ} \mathrm{C}\right) \text {, } \\
\text { masing-masing diuji dengan konsentrasi } 20 \%, 40 \%, 60 \%, 80 \% \text { dan } 100 \% \text { kemudian diuji }\end{array}$ \\
\hline $\begin{array}{l}\text { Keyword: } \\
\text { alga hijau, } \\
\text { antibakteri, } \\
\text { S.thypi, S.aureus, } \\
\text { pantai luk }\end{array}$ & $\begin{array}{l}\text { secara in vitro terhadap Salmonella thypi dan Staphylococcus aureus. Pengujian } \\
\text { antibakteri alga hijau menunjukkan zona hambat yang berbeda pada setiap jenis ekstraksi } \\
\text { dan kosentrasi kedua bakteri patogen. Zona hambat paling besar terhadap s.thypi yaitu } \\
\text { dengan menggunakan ektraksi metode pengeringan kosentrasi } 60 \% \text { dan metode } \\
\text { pemansan } 100 \% \text {, sedangkan paling besar terhadap s.aureusi yaitu dengan menggunakan } \\
\text { ektraksi metode pemanasan kosentrasi } 80 \% \text {. }\end{array}$ \\
\hline
\end{tabular}

\section{PENDAHULUAN}

Indonesia merupakan negara maritim dengan perbandingan luas wilayah lautan dan daratan berbanding 3:1, karena hampir $70 \%$ luas wilayahnya berupa lautan yang memiliki sumber daya alam laut yang melimpah dan beragam baik hayati maupun nonhayati (Alfiyaturohmah dkk., 2014). Salah satu sumber daya alam yang cukup potensial dari perairan laut Indonesia adalah alga (Andriani dkk., 2015). Penyebaran alga terdapat hampir di seluruh perairan Indonesia termasuk di kawasan Laut Luk, Sumbawa.

Alga digunakan sebagai bahan makanan, minuman, kosmetik, dan obat-obatan. Alga juga memiliki kemampuan untuk memproduksi metabolit sekunder yang bersifat sebagai senyawa bioaktif untuk melindungi dirinya dari kondisi lingkungan hidup yang ekstrim seperti salinitas tinggi dan pertahanan diri dari ancaman berbagai penyakit dan predator (Sareong, 2008). Jumlah dan variasi senyawa bioaktif alga sangat banyak dan beragam. Senyawa bioaktif dari alga telah ditemukan penggunaannya sebagai antibakteri (Maduriana dan Sudira, 2009), antioksidan (Suryaningrum dkk., 2006), antijamur (Lutfiyanti dkk., 2012), antikanker (Nurmareta, 2014), dan antiinflamasi (Ariani, 2015).
Alga terdiri atas tiga kelas, yaitu Rhodophyceae (alga merah), Phaeophyceae (alga cokelat), dan Chlorophyceae (alga hijau).

Penyakit infeksi yang disebabkan oleh mikroba patogen terus mengalami peningkatan karena penggunaan antibiotik yang relatif tinggi dan tidak tepat penggunaannya sehingga menimbulkan resisten bakteri pathogen terhadap antibiotik misalnya Staphylococcus aureus, Salmonella thypi (Mardiastuti dkk, 2007). Kondisi tersebut memacu pencarian sumber bahan alam yang dapat menghambat dan membunuh bakteribakteri patogen terutama pada alga hijau.

Jenis rumput laut atau alga hijau yang banyak ditemukan dan cukup melimpah adalah Ulva sp. atau yang disebut dengan selada laut. Alga jenis Ulva sp. digunakan sebagai bahan makanan manusia dan juga makanan ternak, berkhasiat sebagai antibakteri dan mengatasi tekanan darah tinggi (Romimohtarto dan Juwana, 2007).

Populasi alga hijau (Ulva sp.) banyak tersebar di perairan Sumbawa khususnya di Pantai Luk Sumbawa. Hingga saat ini pemanfaatan alga hijau (Ulva $s p$ ) oleh masyarakat belum diketahui baik sebagai makanan maupun obat-obatan dan penelitian mengenai aktivitas antibakteri pada alga hijau (Ulva sp.) dari pantai Luk belum banyak 
dilakukan Berdasarkan hal tersebut maka penulis tertarik untuk melakukan penelitian mengenai uji aktiviatas antibakteri alga hijau (Ulva sp.) dari Pantai Luk Sumbawa terhadap bakteri Staphylococcus aureus dan Salmonella thypi.

Pengujian aktivitas antibakteri dari ekstrak kasar alga hijau dengan pelarut akuades ini dilakukan dengan beberapa preparasi sampel yang dapat digunakan sebagai alternatif yang lebih mudah dalam mempermudah proses penggerusan. Sifat substansi thalus alga yang beranekaragam, ada yang lunak karena tingginya gelatin dan keras karena mengandung zat kapur, yang menyebabkan beberapa jenis tidak mudah dihancurkan (Suparmi dan Sahri, 2009). Tujuan dilakukan penelitian ini adalah untuk mengetahui kemampuan antibakteri alga hijau yang terdapat di Pantai Luk Sumbawa dan metode preparasi terbaik yang dapat digunakan untuk mengoptimalkan proses ekstraksi alga merah dilihat dari zona hambat yang dihasilkan.

\section{MATODE PENELITIAN}

\section{Alat dan Bahan}

Alat yang digunakan dalam penelitian ini adalah mortal pistil (Cole-Parmer), hot plate (Iwaki Ecan HPS-2002), mikropipet (Thermo Scientific), Biosafety Cabinet (BioBase 11231BBC 86), inkubator (Memmert IN75), seperangkat alat kaca (Pyrex Iwaki) (gelas beaker, gelas ukur, labu erlenmeyer, batang pengaduk kaca, tabung reaksi, cawan petri), ose, rak tabung reaksi, tube falcon (Violamo), batang segitiga, timbangan (Precisa XT220A), autoclave (GEA YX-18LM), lemari pendingin (GEA), spatula, bunsen, dan pinset.

Bahan yang digunakan adalah sampel alga hijau, biakan murni bakteri S. thypi dan S. aureus, media NB (Nutrient Broth), agar, akuades, kertas cakram, alumunium foil, kapas, alkohol 70\%, tissue, sarung tangan lateks, masker.

\section{Tahapan Penelitian Pengambilan Sampel}

Sampel diambil di perairan Laut Luk, Sumbawa dan pengambilan sampel dilakukan saat air laut mencapai surut. Sampel yang digunakan adalah alga hijau yang tanpa memperhatikan umur tumbuhan. Sampel yang telah diambil dibersihkan dari substratnya dan dicuci hingga bersih (Sukmawaty dkk., 2016).

\section{Identifikasi Alga Hijau}

Identifikasi dari setiap genus dan spesies yang didapatkan, didasarkan pada pengamatan morfologi dan pedoman praktis identifikasi alga laut (Atmaja, dkk., 1996; Trono, 1997).

\section{Ekstraksi Sampel}

Sampel yang telah dibersihkan selanjutnya masing-masing jenis alga diberlakukan dengan tiga metode berbeda yaitu dibekukan pada suhu $-10{ }^{\circ} \mathrm{C}$ selama 24 jam, dipanaskan selama 1 jam pada suhu 70-80 ${ }^{\circ} \mathrm{C}$, dan dikeringkan dengan cara dijemur tanpa penyinaran matahari secara langsung selama 4 hari untuk menghindari berubah atau rusaknya komponen senyawa bioaktif yang terdapat pada sampel. Alga hijau kemudian dihaluskan mengunakan mortar pistil guna memecah dinding sel sampel dan memperluas permukaan sampel, sehingga mempermudah kontak antara pelarut dan sampel, senyawa bioaktif yang terdapat dalam sampel dapat terbawa sempurna saat ekstaksi maserasi (Setyati dkk., 2017). Kemudian dimaserasi dengan menggunakan pelarut air/akuades steril dengan perbandingan 1:1 selama $2 \times 24$ jam pada $27^{\circ} \mathrm{C}$. Hasil maserasi dipisahkan antara filtrat dan residunya dengan penyaringan, sehingga diperoleh ekstrak kasar.

\section{Peremajaan Bakteri Uji}

$$
\text { Bakteri Salmonella thyphi dan }
$$

Staphylococcus aureus yang berasal dari biakan murni, masing-masing diambil sebanyak satu ose kemudian ditumbuhkan atau diinokulasikan dengan cara digores pada medium Nutrient Agar (NA) miring. Kultur bakteri pada agar miring diinkubasi pada suhu $37^{\circ} \mathrm{C}$ selama 24 jam (Nurwahida, 2018).

\section{Pembuatan Suspensi Bakteri Uji}

Bakteri uji yang telah diremajakan selama 24 jam, masing-masing diambil satu ose kemudian disuspensikan ke dalam media Nutrient Broth (NB), setelah itu dihomogenkan. Kultur cair diinkubasi pada suhu $37{ }^{\circ} \mathrm{C}$ selama 24 jam (Nuria, 2010). Kekeruhan pada media diamati yang menandakan adanya perbanyakan sel bakteri (Lestari dkk., 2014).

\section{Penyiapan Bahan Ekstrak Alga Hijau dalam Berbagai Konsentrasi}

Ekstrak kasar dari ketiga metode berbeda dimasukkan dalam botol pengenceran masingmasing $200 \mu \mathrm{L}, 400 \mu \mathrm{L}, 600 \mu \mathrm{L}, 800 \mu \mathrm{L}$ dan 1000 $\mu \mathrm{L}$. Selanjutnya ditambahkan dengan akuades steril hingga masing-masing larutan berjumlah $1 \mathrm{~mL}$. Hasil pengenceran tersebut diperoleh ekstrak dengan berbagai konsentrasi berbeda, masingmasing 20\%, 40\%, 60\%, $80 \%$ dan $100 \%$. Selanjutnya kelima konsentrasi ekstrak dalam botol tersebut dihomogenkan dengan cara digojok.

\section{Uji Aktivitas Antibakteri}

Uji aktivitas antibakteri dilakukan secara in vitro menggunakan uji sensitivitas antibakteri dengan metode difusi agar dengan menggunakan kertas cakram (Bachtiar dkk., 2012). Kertas cakram direndam dalam larutan ekstrak kasar dan larutan kontrol (akuades steril) masing- masing sebanyak 9 lembar selama 30 menit. Media pertumbuhan bakteri uji yang digunakan media NA. Sebanyak 
$100 \mu \mathrm{L}$ bakteri uji yang telah dikultur selama 24 jam diratakan menggunakan spreader/batang segitiga pada media pertumbuhan bakteri. Selanjutnya kertas cakram yang telah direndam pada masingmasing ekstrak dan kontrol negatif ditempelkan pada permukaan media NA yang telah diolesi suspensi bakteri. Letak kertas cakram pada permukaan media diatur sedemikian rupa dan tidak terlalu berdekatan agar zona hambat yang terbentuk nantinya tidak saling bertabrakan satu sama lainnya. Masing-masing perlakuan dengan tiga ulangan. Cawan petri kemudian diinkubasi pada suhu $37^{\circ} \mathrm{C}$ selama 24 jam. Setelah masa inkubasi 24 jam, pertumbuhan bakteri dan zona bening yang timbul di sekitar kertas saring diukur diameternya. Diameter zona hambat ditentukan dengan cara mengurangi diameter keseluruhan (cakram + zona hambatan) dengan diameter cakram $(6 \mathrm{~mm})$ dan diameter zona hambat pelarut (jika pelarut memberikan zona hambatan) (Andriani dkk., 2015).

\section{Analisis Data}

Data yang telah diperoleh berupa nilai diameter zona hambat hasil uji aktivitas antibakteri yang diolah secara statistik dengan Analysis of Variance (ANOVA), apabila perlakuan yang diberikan menunjukkan pengaruh yang nyata, maka dilanjutkan dengan uji Jarak Berganda Duncan dengan taraf kepercayaan $95 \%$ yang bertujuan untuk mengetahui metode preparasi ekstrak dan konsentrasi perlakuan yang terbaik. Analysis of Variance (ANOVA) maupun uji Jarak Berganda Duncan dilakukan dengan menggunakan SPSS versi 16 (Bachtiar dkk., 2012).

\section{HASIL DAN PEMBAHASAN}

\section{Identifikasi Alga Hijau}

Berdasarkan hasil penelitian didapatkan ciri-ciri sampel alga yang diketahui bahwa termasuk kelompok alga hijau (ulva sp) yang terdapat di Pantai Luk. Adapun Klasifikasi jenis alga hijau yang ditemukan dapat dilihat pada Tabel 1 .

Tabel 1. Klasifikasi Rhodophyta di Pantai Luk, Sumbawa.

\begin{tabular}{lc}
\hline Kelas & Chlorophyceae \\
Ordo & Ulotrichales \\
Famili & Ulva \\
Genus & Ulva \\
Spesies & Ulva sp \\
\hline
\end{tabular}

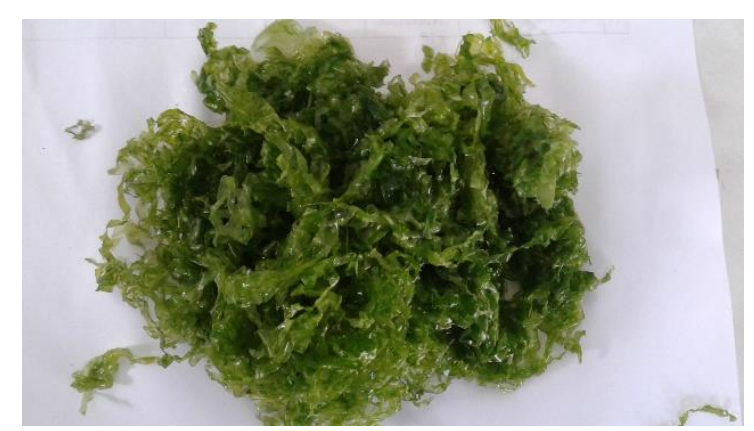

Gambar 1. Alga Hijau Ulva sp di Pantai Luk, Sumbawa (Sumber : Dok.Pribadi.2017).

Identifikasi jenis alga anggota divisi alga hijau yang ditemukan di Pantai Luk diidentifikasi dengan pengamatan karakter morfologi. Struktur morfologis alga merah mulai dari bentuk filament, bercabang, berbentuk bulu, dan lembaran. Pengamatan karakter ini lebih cepat dan lebih mudah untuk dilakukan dalam identifikasi (Oryza dkk., 2017). Hasil identifikasi karakter morfologi adalah sebagai berikut:

Alga hijau (Ulva sp) memiliki ciri-ciri thalus menyerupai lembaran (berupa lembaran lebar maupun kecil), thalus yang berupa lembaran kecil membentuk rumpun meyerupai jaring dengan berekspansi radial, tepi lembaran berombak, warna hijau cerah hingga hijau tua, thalus berwarna gelap pada bagian tertentu (terutama dekat dengan bagianpangkal karena ada sedikit penebalan).

\section{Preparasi Sampel dan Ekstraksi Alga Hijau}

Sampel yang digunakan dalam penelitian ini adalah alga hijau yang diperoleh dari Pantai Luk, Sumbawa. Sampel diberi perlakuan berbeda pada tahap preparasi sampel yaitu sampe dikeringkan, dibekukan, dan dipanaskan. Sampel dikeringkan untuk menurunkan kadar air. Pengeringan dilakukan pada suhu $27{ }^{\circ} \mathrm{C}$ bertujuan untuk meminimalisir kadar air yang terkandung dalam alga sehingga menghambat aktivitas mikroorganisme (jamur maupun bakteri) dan menghindari kerusakan senyawa aktif pada sampel yang tidak tahan panas (Alfiyaturohmah dkk., 2014). Sampel dibekukan pada suhu $-10{ }^{\circ} \mathrm{C}$ untuk mempermudah proses penghalusan dan mendapatkan ekstrak dari alga segar, sedangkan dipanaskan pada suhu $70-80{ }^{\circ} \mathrm{C}$ bertujuan untuk membantu merusak dinding sel alga sehingga mempermudah proses ekstraksi.

Penghalusan dilakukan dengan tujuan memperluas permukaan sampel, sehingga mempermudah kontak antara pelarut dan sampel pada saat ekstraksi maserasi. Ekstraksi senyawa aktif alga hijau menggunakan metode maserasi dengan pelarut air/akuades. Metode maserasi dipilih karena metode ini menguntungkan dalam 
isolasi bahan alam disebabkan karena dengan perendaman, sampel alga akan mengalami pemecahan dinding dan membran sel akibat perbedaan tekanan antara di dalam dan di luar sel sehingga metabolit sekunder yang ada di dalam sitoplasma akan terlarut dalam pelarut (Hanapi dkk., 2013). Penggunaan pelarut air pada proses ekstraksi senyawa aktif pada alga dikarenakan air bersifat polar. Menurut Suryaningrum dkk. (2006) ekstrak senyawa bioaktif lebih banyak yang bersifat polar daripada nonpolar pada beberapa spesies alga seperti Halymenia harveyana dan Eucheuma cottoni. Selain itu, di antara pelarut yang sifatnya polar, air dapat dikatakan paling aman dan mudah didapatkan.

\section{Aktivitas Antibakteri dari Ekstrak Kasar Alga Hijau Ulva sp}

Uji aktivitas antibakteri merupakan metode pengujian yang dilakukan untuk mengetahui kemampuan suatu bahan dalam menghambat pertumbuhan bakteri (Andriani dkk., 2015). Pengujian ini dilakukan terhadap bakteri $S$. thypi (Gram negatif) dan bakteri $S$. aureus (Gram positif) secara in vitro dengan metode difusi cakram. Penentuan zona hambat dilakukan dengan cara mengamati zona bening yang berada di zona terluar kertas cakram yang mengandung ekstrak alga hijau pada media agar yang telah ditumbuhi bakteri. Semakin besar zona hambat maka semakin besar pula kemampuan ekstrak alga hijau dalam menghambat pertumbuhan bakteri. Hasil pengamatan uji antibakteri setelah masa inkubasi 24 jam (Tabel 2) menunjukkan bahwa preparasi sampel terbaik yang digunakan untuk menghasilkan zona hambat dari ekstrak kasar alga hijau terhadap Salmonella thypi dengan metode pengeringan dengan kosentrasi $60 \%$ dan metode pemanasan dengan kosentrasi $100 \%$. Berdasarkan data yang didapatkan, ekstrak dengan menggunakan metode pengeringan kosentrasi $60 \%$ dan metode pemanasan kosentrasi $100 \%$ berpengaruh nyata $(\mathrm{p}<0,05)$ terhadap pertumbuhan bakteri S.thypi. Dimana pada ekstrak kasar alga hijau metode pengeringan kosentrasi $60 \%$ didapatkan zona hambat sebesar $9,33 \mathrm{~mm}$, sedangkan pada ekstrak kasar alga hijau metode pemanasan kosentrasi $100 \%$ didapatkan zona hambat sebesar 10,67 mm, dimana ekstraksi metode pemanasan kosentrasi $100 \%$ memiliki diameter zona hambat yang lebih besar dibandingkan ekstrak alga hijau metode pengeringan kosentrasi $60 \%$. Sedangkan preparasi sampel terbaik yang digunakan untuk menghasilkan zona hambat dari ekstrak kasar alga hijau terhadap Staphylococcus aureus yaitu dengan metode pemanasan kosentrasi $80 \%$. Berdasarkan data yang didapatkan, ekstra dengan menggunakan metode pemanasan kosentrasi $80 \%$ berpengaruh nyata $(\mathrm{p}<0,05)$ terhadap pertumbuhan bakteri S.aureus, dimana pada ekstrak kasar alga hijau metode pemanasan kosentrasi $80 \%$ didapatkan zona hambat sebesar 3,33 mm. Sehingga ektrak dengan menggunakan metode pemanasan kosentrasi $80 \%$, memberikan diameter zona hambat terbesar terhadap pertumbuhan S.aureus.

Tabel 2. Hasil Pengamatan Aktivitas Antibakteri Alga Hijau Ulva sp

\begin{tabular}{|c|c|c|}
\hline \multirow[t]{2}{*}{ Perlakuan } & \multicolumn{2}{|c|}{$\begin{array}{c}\text { Diameter Zona Hamba } \\
(\mathrm{mm})\end{array}$} \\
\hline & S.thypi & S. aureus \\
\hline Kontrol (0) & $0,00 \mathrm{a}$ & $0,00 \mathrm{a}$ \\
\hline Pengeringan $20 \%$ & $3,33 \mathrm{ab}$ & 1,00ab \\
\hline Pengeringan $40 \%$ & $3,00 \mathrm{ab}$ & $1,33 \mathrm{abc}$ \\
\hline Pengeringan $60 \%$ & $9,33 \mathrm{c}$ & $2,00 \mathrm{bcd}$ \\
\hline Pengeringan $80 \%$ & $4 b$ & $2,00 \mathrm{bcd}$ \\
\hline Pengeringan $100 \%$ & $1,33 \mathrm{ab}$ & $2,33 \mathrm{bcd}$ \\
\hline Pemanasan $20 \%$ & $0,00 \mathrm{a}$ & $2,67 \mathrm{~cd}$ \\
\hline Pemanasan $40 \%$ & $0,00 \mathrm{a}$ & $1,67 \mathrm{bc}$ \\
\hline Pemanasan $60 \%$ & $0,00 \mathrm{a}$ & $1,67 b c$ \\
\hline Pemanasan $80 \%$ & $0,00 \mathrm{a}$ & $3,33 \mathrm{~d}$ \\
\hline Pemanasan $100 \%$ & $10,67 \mathrm{c}$ & $1,00 \mathrm{ab}$ \\
\hline Pendinginan $20 \%$ & $0,00 \mathrm{a}$ & $1,33 \mathrm{abc}$ \\
\hline Pendinginan $40 \%$ & $1,00 \mathrm{ab}$ & $1,33 a b c$ \\
\hline Pendinginan $60 \%$ & $2,67 \mathrm{ab}$ & $1,67 b c$ \\
\hline Pendinginan $80 \%$ & $3,33 \mathrm{ab}$ & $2,33 \mathrm{bcd}$ \\
\hline Pendinginan $100 \%$ & 3,33ab & $2,00 \mathrm{bcd}$ \\
\hline
\end{tabular}

Dengan demikian, jika dilakukan analisa, ekstraksi alga hijau Ulva sp dengan menggunakan metode pemanasan dapat berpengaruh nyata terhadap pertumbuhan bakteri Salmonella thypi dan Staphylococcus aureus.

\section{PENUTUP}

\section{Kesimpulan}

Alga hijau Ulva $s p$ memiliki potensi antibakteri terhadap bakteri S.thypi dan S.Aureus. Metode ekstraksi pengeringan kosentrasi $60 \%$ dan metode pemanasan kosentrasi $100 \%$ memberikan pengaruh nyata terhadap pertumbuhan bakteri S.thypi. Sedangkan metode ektraksi Pemanasan kosentrasi $80 \%$ memberikan pengaruh nyata terhadap pertumbuhan bakteri S.aureus. Metode Pemanasan memberikan pengaruh nyata terhadap pertumbuhan bakteri S.thypi dan S.aureus. 


\section{REFERENSI}

Alfiyaturohmah, Ningsih, R. dan Yusnawan, E. 2014. Uji Aktivitas Antibakteri Ekstrak Kasar Etanol, Kloroform dan N-Heksana Alga Coklat Sargassum vulgare Asal Pantai Kapong Pamekasan Terhadap Bakteri Staphilococcus aureus dan Eschericia coli. ALCHEMY: Journal of Chemistry, 3 (1): 5766.

Amaranggana, L. dan Wathoni, N. 2017. Manfaat Alga hijau (Rhodopyta) sebagai Sumber Obat dari Bahan Alam. Majalah Farmasetika, 2 (1): 16-19.

Ariani, D.F. 2015. Identifikasi Efek Antiinflamasi Ekstrak Alga Coklat Padina sp terhadap Mencit. Skripsi. Fakultas Kedokteran Gigi Universitas Hasanuddin. Makassar.

Atmaja, W.S., Kadi, A., Sulistijo dan Rachmaniar, S. 1996. Pengenalan JenisJenis Rumput Laut Indonesia. Jakarta: Puslitbang Oseanologi LIPI.

Bachtiar, S.Y., Tjahjaningsih, W. dan Sianita, N. 2012. Pengaruh Ekstrak Alga Cokelat (Sargassum sp.) Terhadap Pertumbuhan Bakteri Escherichia coli. Journal of Marine and Coastal Science, 1 (1): 53-60.

Dali, S., Natsir, H., Usman, H. dan Ahmad, A. 2011. Bioaktivitas Antibakteri Fraksi Protein Alga hijau Gelidium amansii dari Perairan Cikoang Kabupaten Takalar, Sulawesi Selatan. Majalah Farmasi dan Farmakologi, 5(1): 47-52.

Ekawati, E.V., Husnul, S.N. dan Herawati, D. 2018. Identifikasi Kuman pada Pus dari Luka Infeksi Kulit. Jurnal SainHealth, 2 (1): 31-35.

Ernawati dan Sari, K. 2015. Kandungan Senyawa Kimia dan Aktivitas Antibakteri Ekstrak Kulit Buah Alpukat (Persea Americana P.Mill) terhadap Bakteri Vibrio alginolyticus. Jurnal Kajian Veteriner, 3(2): 203-211.

Hamza, A.H., Al-Bishri, W., Omar, H.H. dan Danial, E.N. 2014. Potential Antimicrobial, Antioxidant and Anityrosenase Activities Achieved by Selected Species of Marine Macroalgae. Journal of Pure and Applied Microbiology, 8 (1): 257-265.
Hanapi, A., Fasya, A.G., Mardiyah, U. dan Miftahurrahmah. 2013. Uji Aktivitas Antioksidan dan Antibakteri Ekstrak Metanol Alga hijau Eucheuma spinosum. ALCHEMY: Journal of Chemistry, 2 (2): 126-137.

Handayani, S., Setia, T.M. dan Rahayu, S.E. 2014. Pengenalan Makroalga Indonesia. Jakarta: Dian Rakyat.

Kasanah, N., Triyanto, Seto, D.S., Amelia, W. dan Isnansetyo, A. 2015. Antibacterial Compounds from Red Seaweeds (Rhodophyta). Indones. J. Chem.,15 (2): 201-209.

Langoy, M.L.D., Saroyo, Dapas, F.N.J., Katili, D.Y. dan Hamsir, S.B. 2011. Deskripsi Alga Makro Di Taman Wisata Alam Batuputih, Kota Bitung. Jurnal Ilmiah Sains, 11 (2): 219-224.

Lestari, N., Roza, R.M. dan Martina, A. 2014. Analisis Fisiologi Bakteri Lignoselulolitik dan Aktinomisetes Selulolitik dan Ligninolitik dari Tanah Gambut Desa Rimbo Panjang Kabupaten Kampar sebagai Agen Biokompos. JOM FMIPA, 1 (2): 571580 .

Lutfiyanti, R., Ma'ruf, W.F. dan Dewi, E.N. 2012. Aktivitas Antijamur Senyawa Bioaktif Ekstrak Gelidium latifolium terhadap Candida albicans. Jurnal Pengolahan dan Bioteknologi Hasil Perikanan, 1 (1): $1-8$.

Maduriana, I M. dan Sudira, I W. 2009. Skrining dan Uji Aktivitas Antibakteri Beberapa Rumput Laut dari Pantai Batu Bolong Canggu dan Serangan. Buletin Veteriner Udayana, 1 (2): 69-76.

Maheswari, U.M. dan Reena, A. 2017. Phytochemical Profiling of the Red Seaweed, Halymenia dilatata by GCMS Analysis. International Journal of Pharma Sciences and Research, 8 (8): 167-172.

Marianingsih, P., Amelia, E. dan Suroto, T. 2013. Inventarisasi dan Identifikasi Makroalga di Perairan Pulau Untung Jawa. Prosiding Semirata FMIPA Universitas Lampung: 219-223. 
Lampung, 10-12 Mei 2013: FMIPA

Unila.

Moosa, M.K. 1999. Sumberdaya Laut Nusantara, Keanekaragaman Hayati Laut dan Pelestariannya. Loka Karya Keanekaragaman Hayati Laut. Pemanfaatan Secara Lestari Dilandasi Penelitian dan Penyelamatan. Widy Graha LIPI. Jakarta, 23 Februari 1999.

Ngajow, M., Abidjulu, J. dan Kamu, V.S. 2013. Pengaruh Antibakteri Ekstrak Kulit Batang Matoa (Pometia pinnata) terhadap Bakteri Staphylococcus aureus secara in vitro. Jurnal MIPA Unsrat Online 